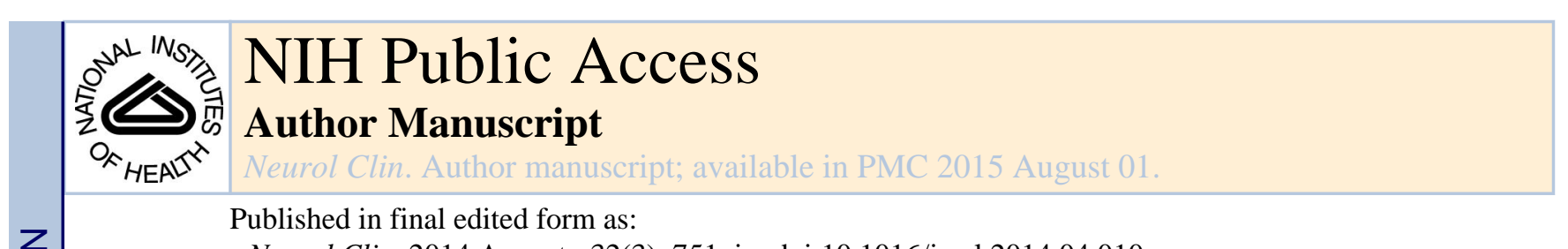

Published in final edited form as:

Neurol Clin. 2014 August ; 32(3): 751-ix. doi:10.1016/j.ncl.2014.04.010.

\title{
Pompe Disease: Literature Review and Case Series
}

\section{Majed Dasouki, MD,}

Department of Neurology, University of Kansas Medical Center, 3901 Rainbow Boulevard, Kansas City, Kansas, 66160, USA. mdasouki@kumc.edu

Department of Genetics, King Faisal Specialist Hospital \& Research Center, MBC-03-30. PO Box 3354. Riyadh, 11211. Saudi Arabia, Tel.\# (966-11) 4647272, extension 31768,

madasouki@kfshrc.edu.sa

Omar Jawdat, MD,

Department of Neurology, University of Kansas Medical Center, Mailstop 2012, 3901 Rainbow Boulevard, Kansas City, KS 66160, USA, ojawdat@kumc.edu, Tel: 913-588-6970

\section{Osama Almadhoun, MD,}

Department of Pediatrics, University of Kansas Medical Center, Mailstop 4004, 3901 Rainbow

Boulevard, Kansas City, KS 66160, oalmadhoun@kumc.edu, Tel: 913-588-6326

Mamatha Pasnoor, MD,

mpasnoor@kumc.edu, Mailstop 2012, 3901 Rainbow Boulevard, Kansas City, KS 66160, Tel: 913-588-6970

\section{April L. McVey, MD,}

Department of Neurology, University of Kansas Medical Center; Mailstop 2012, 3901 Rainbow

Boulevard, Kansas City, KS 66160, amcey@kumc.edu, Tel: 913-588-6970

\section{Ahmad Abuzinadah, MD, \\ Department of Neurology, University of Kansas Medical Center Mailstop 2012; 3901 Rainbow \\ Boulevard, Kansas City, KS 66160, aabuzinadah@kumc.edu, Tel: 913-588-6970 \\ Laura Herbelin, BS, \\ Department of Neurology, University of Kansas Medical Center, Mailstop 2012; 3901 Rainbow \\ Boulevard, Kansas City, KS 66160, Iherbelin@kumc.edu, Tel: 913-588-6970 \\ Richard J. Barohn, MD, and \\ Department of Neurology, University of Kansas Medical Center, Mailstop 2012, 3901 Rainbow \\ Boulevard, Kansas City, KS 66160, rbarohn@kumc.edu, 913-588-6094}

\section{Mazen M. Dimachkie, MD}

Correspondence to: Majed Dasouki.

Majed Dasouki,M.D. Current address: Department of Genetics, King Faisal Specialist Hospital \& Research Center, MBC-03-30. PO Box 3354. Riyadh, 11211. Saudi Arabia, Tel.\# (966-11) 4647272, extension 31768, madasouki@kfshrc.edu.sa

Financial disclosures and/or conflicts of interest: The following authors declare clinical trials support by Genzyme Corporation (Majed Dasouki, Richard Barohn, Osama Almadhoun) and Amicus Therapeutics (Majed Dasouki, Mazen M. Dimachkie); travel support by Genzyme Corporation (Majed Dasouki, Richard J. Barohn, Mazen M. Dimachkie) and honoraria by Genzyme Corporation (Mazen M. Dimachkie, Richard J. Barohn). 
Department of Neurology, University of Kansas Medical Center mdimachkie@kumc.edu, 913-588-6970; Mailstop 2012; 3901 Rainbow Boulevard, Kansas City, KS 66160

\section{Keywords}

Metabolic Myopathy; Hypotonia; Autosomal recessive; Enzyme Replacement Therapy; Newborn Screening; Lysosomal glycogen storage disease

\section{INTRODUCTION}

Pompe disease (GSD II) is an autosomal recessive disorder caused by deficiency of the lysosomal enzyme acid-a-glucosidase (GAA, EC 3.2.1.20), leading to generalized accumulation of lysosomal glycogen especially in the heart, skeletal and smooth muscle, and the nervous system. Pompe disease was first described in a 7 month-old girl with severe muscle weakness who also had hypertrophic cardiomyopathy and generalized glycogen accumulation in various tissues throughout the body. ${ }^{1}$ Bischoff and Putschar also independently described the disease in the same year. ${ }^{2,3}$ Hers identified alpha-glucosidase deficiency and localized the GAA enzyme activity to the lysosomes of liver, heart and muscle tissues of five infants with classic Pompe disease and was the first to recognize impaired autophagy. ${ }^{4}$ Pompe disease is generally classified based on the age of onset as infantile (IOPD) when it presents during the first year of life, and late onset (LOPD) when it presents afterwards. Childhood, juvenile and adult-onset Pompe disease are examples of the late onset form. IOPD associated with cardiomyopathy is referred to as classic Pompe disease and in the absence of cardiomyopathy as non-classic Pompe disease. ${ }^{5,6,7}$ Similar to other lysosomal storage disorders, Pompe disease clinically presents as a continuum in its age of onset and multisystem involvement. The role of autophagy in the pathogenesis of Pompe disease, especially the late onset form, has increasingly become evident and may be clinically relevant. Autophagy (self-eating) is a highly complex, ubiquitously expressed, and evolutionarily conserved lysosomal degradative process, which is controlled by a multi-gene network (http://autophagy.lu/index.html). Its main function is to recycle obsolete cellular constituents and eliminate damaged organelles and protein aggregates. It involves dynamic membrane rearrangement for sequestration of cytoplasm and its delivery into the vacuole/ lysosome. Basal autophagy plays a role in cellular development and differentiation, ${ }^{8}$ innate and adaptive immunity ${ }^{9}$ and is induced in response to various stress conditions, such as nutrient limitation, heat, and oxidative stress. Ammonia derived from the deamination of glutamine via glutaminolysis supports basal autophagy and protects cells from tumor necrosis factor alpha (TNFa)-induced cell death. ${ }^{10}$ As a result basic metabolites are released into the cytoplasm for new synthesis or as sources for energy. Autophagy is also implicated in a wide range of disorders such as neurodegeneration, cancer and ageing and now various lysosomal storage diseases especially Pompe disease. ${ }^{11-14}$

Clinically, infants with classic Pompe disease typically present during the first few weeks of life with hypotonia, progressive weakness, macroglossia, hepatomegaly and hypertrophic cardiomyopathy. With this typical clinical presentation, diagnosis is usually straightforward. The natural history of IOPD is that most of these infants die by their first birthday. On the 
other hand, the diagnosis of Pompe disease in older children and adults can be more challenging as these patients generally present with slowly progressive limb girdle type weakness and respiratory insufficiency without significant cardiomyopathy. ${ }^{5-7,15}$ Cardiac involvement in late-onset Pompe disease manifests as Wolff-Parkinson-White syndrome, left ventricular hypertrophy and dilatation of the ascending aorta. Rigid spine syndrome (a progressive limitation of the neck and trunk), scoliosis, and low body weight had also been reported in a subset of patients with LOPD with onset in adolescence and resulting in postural anomalies. ${ }^{16}$ The diagnosis of Pompe disease is usually made based on typical clinical presentation followed by the demonstration of deficiency of GAA enzyme activity in muscle, skin fibroblasts or more recently dried blood spots (DBS) as well as GAA mutation analysis. ${ }^{5,6}$ Diagnosis of Pompe disease through newborn screening is also now possible. Pompe disease is still considered to be a rare inborn error of metabolism with an estimated frequency of about 1/40,000 and a higher incidence in certain populations such as African Americans (1/14,000), Northern Europeans of Dutch origin and South East Asians. However, early results of newborn screening pilot studies from Taiwan and USA indicated a higher incidence. Interest in Pompe disease has grown significantly since the FDA approval of the first specific enzyme replacement therapy (ERT) with recombinant human acid aglucosidase (alglucosidase alfa) for this metabolic myopathy in 2006. Glycosylated alglucosidase alfa is targeted to the lysosomes through uptake via the mannose-6-phosphate receptors. Clinical experience with alglucosidase alfa showed more dramatic improvement of cardiac pathology compared to skeletal myopathy and especially in children more than adults. Abnormal autophagy in Pompe disease results in abnormal recycling of the cation independent mannose-6-phosphate receptors (CI-M6PR), which may explain the less satisfactory clinical response of skeletal muscles. ${ }^{17,18}$ Therefore, correction of abnormal autophagy in individuals with Pompe disease may improve therapeutic response to ERT.

In this report, we describe our experience with 12 patients with classic infantile ( 1 child), non-classic infantile (2 siblings), juvenile (1) and adult onset (8) Pompe disease one of whom had a first trimester miscarriage while receiving ERT. We also report 4 potentially pathogenic, novel GAA gene variants in this group and review the recent advances in the pathogenesis, diagnosis and treatment of individuals with Pompe disease.

\section{Genetic Etiology and Prevalence}

Pompe disease is also considered a polyglucosan vacuolar myopathy which results from absence or partial deficiency of the lysosomal acid a-glucosidase (GAA) activity due to recessive mutations in the autosomal GAA gene. GAA (NM_000152.3) is approximately $18.3 \mathrm{~kb}$ long and contains 20 exons (Fig.1). Its cDNA has 2859 nucleotides of coding sequence which encode the immature 952 amino acid enzyme. GAA is synthesized as a membrane bound, catalytically inactive precursor which is sequestered in the endoplasmic reticulum. It undergoes sugar chain modification in the Golgi complex, followed by transport into the (minor) secretory pathway, or into lysosomes where it is trimmed in a stepwise process at both the amino- and carboxyl-termini. ${ }^{19,20}$ Phosphorylation of mannose residues ensures efficient transport of the enzyme to the lysosomes via the mannose 6phosphate receptor. GAA catalyzes the hydrolysis of $a 1 \rightarrow 4$ glucosidic linkages in glycogen at acid $\mathrm{pH}$. Specificity for the natural substrate (glycogen) is gained during its maturation. 
The activity of mature (76/70-kDa) GAA for its natural (glycogen) substrate is considerably more robust than its activity towards the artificial substrate (4-methylumbelliferyl-a-Dglucopyranoside4; 4-MU), which is frequently used in in-vitro assays. ${ }^{20}$ However, 4-MU is also a substrate for several other enzymes including "leukocyte" neutral isoenzymes, glucosidase II (GANAB) and neutral a-glucosidase C (GANC), and maltase glucoamylase (MGAM). Muscle tissue and cultured fibroblasts do not contain MGAM allowing measurement of GAA (as the activity ratio of neutral to acid glucosidase, GANAB + GANC/GAA) without interference. Because MGAM is expressed in neutrophils, not in lymphocytes, the same activity ratio determined in purified lymphocytes has also been used for the diagnosis of GSD II which is not possible in dried blood spots (DBS). Using maltose or acarbose as an inhibitor of MGAM activity, the measurement of GAA activity in DBS samples with minimal interference by other a-glucosidases was accomplished which now serves as the basis for newborn screening and the non-invasive diagnosis for Pompe disease. ${ }^{21-23}$ As a result, multiplex newborn screening for Pompe disease and other lysosomal storage disorders using fluorometric, digital microfluidic and tandem mass spectrometry based GAA enzyme activity assays had been developed. ${ }^{24-27}$ In addition to qualitative and quantitative assessments of the disease burden, and clinical measures of the impact of Pompe disease on various affected systems, urinary glucose tetrasaccharide (Glc4), a biomarker of glycogen storage with $94 \%$ sensitivity and $84 \%$ specificity for Pompe disease, is frequently used in monitoring the response of patients to enzyme replacement therapy and as an adjunct to acid a-glucosidase activity measurements. ${ }^{28}$ Also, in addition to the traditional 1-dimensional thin layer chromatography (TLC) for urine oligosaccharide analysis, a new MALDI-time-of-flight/time-of-flight (MALDI-TOF/TOF) mass spectrometry based assay of urinary free oligosaccharides useful for the diagnosis of Pompe disease and other lysosomal storage diseases is now available. ${ }^{29}$

Infants with Pompe disease are considered as cross reactive immunologic material (CRIM) positive if they have residual GAA enzyme activity and CRIM negative if no residual GAA activity is detected. Based on pooled clinical studies data, $28 \%$ of Pompe disease cases are infantile-onset, of which about $85 \%$ are classic infantile-onset and three quarters of those are CRIM+(http://www.hrsa.gov/advisorycommittees/mchbadvisory/heritabledisorders/ nominatecondition/reviews/pompereport2013.pdf). CRIM status is usually determined by Western blot analysis in cultured skin fibroblasts, a process that can take a few weeks, and more recently via a blood-based CRIM assay that can yield results within 48 to 72 hours. ${ }^{30}$ Recombinant human acid a-glucosidase (rhGAA) was first produced in dihydrofolate reductase deficient Chinese hamster ovary $(\mathrm{CHO})$ cells, was targeted to heart muscle and corrected glycogen accumulation in fibroblasts from patients with Pompe disease. ${ }^{31}$ Prior to the initiation of enzyme replacement therapy, rapid determination of CRIM status in patients with infantile onset Pompe disease who at risk of developing neutralizing antibodies against rhGAA is extremely important.

Many normal allelic variants exist in $G A A$ and are responsible for the three known alloenzymes (GAA1, GAA2, and GAA4). More than 450 mutations in GAA have been reported in individuals with Pompe disease. Nonsense mutations, large and small gene rearrangements, and splicing defects have been observed with any mutations being 
potentially specific to families, geographic regions, or ethnicities (http://

www.pompecenter.nl/). Combinations of mutations that result in complete absence of GAA enzyme activity are seen more commonly in individuals with infantile-onset disease, whereas those combinations that allow partial enzyme activity typically have a later-onset presentation. ${ }^{32}$ GAA mutations result in mRNA instability and/or severely truncated acid alpha-glucosidase or an enzyme with markedly decreased activity. By means of homology modeling, and using the crystal structure of the N-terminal subunit of human intestinal maltase-glucoamylase as a template, analysis of the three-dimensional models of human GAA encompassing 27 relevant amino acid substitutions causing a processing or transport defect responsible for Pompe disease showed that they were widely spread over all of the five domains of GAA from the core to the surface of the enzyme and the predicted structural changes varied from large to very small. ${ }^{33}$

The c.1726 G>A (p.G576S) variant in cis with c.2065 G>A (p.E689K), also known as the c. [1726A; 2065A] pseudodeficiency allele, causes low GAA activity in normal individuals and is relatively common in Asian populations. ${ }^{34,35}$ About $3.9 \%$ of apparently healthy Japanese were reported to be homozygous for this pseudodeficiency allele which may complicate newborn screening (NBS) and result in a high false positive rate in such populations. ${ }^{36}$ In their newborn screening pilot program in Taiwan, Labrousse et al. identified 36 babies $(0.027 \%$ screened) who had no pathogenic $G A A$ mutation but were homozygous for the c.[1726A;2065A] pseudodeficiency allele. ${ }^{37}$ In the United States, the prevalence of Pompe disease is approximately 1 in 28,000 with the prevalence of pseudodeficiency being less than $1 \%$ as confirmed by genetic analysis of healthy individuals with low GAA enzyme activity level. ${ }^{88}$

\section{Clinical Presentation}

Diagnosis of Pompe disease can be made clinically based on a typical clinical presentation as in infantile cases or suspected in a young child or adult with limb weakness, difficulty walking or limb girdle dystrophy. In combination with the clinical diagnosis, a histological diagnosis can be confirmed in a muscle biopsy which shows typical intra-myofibrillar cytoplasmic membrane bound glycogen, periodic acid-Schiff-positive vacuolar myopathic abnormalities and acid phosphatase positive vacuoles (Fig.2) ${ }^{38-42}$ Low GAA activity in muscle, skin fibroblasts and more recently dried blood spots confirms the diagnosis even in the absence of diagnostic histological findings which are not regularly detected in patients with LOPD. Patients presenting with either a limb-girdle syndrome or dyspnea secondary to diaphragm weakness should undergo further testing. A blood-based GAA enzyme activity assay is the recommended tool to screen for GAA enzyme deficiency, confirmed by a second test: either a second GAA enzyme activity assay in another tissue (such as lymphocytes, fibroblasts or muscle) or GAA gene sequencing. ${ }^{43}$ Deficient GAA enzyme activity leads to generalized tissue lysosomal glycogen accumulation especially in skeletal, cardiac, and smooth muscles. ${ }^{44,45}$ Typically, affected newborns present with hypotonia, upper and low limb weakness, macroglossia, hepatomegaly, failure to thrive, progressive hypertrophic cardiomyopathy and cardio-respiratory insufficiency leading (if untreated) to early death. Generalized glycogen storage had been identified in autopsy material from fetal tissues and adults with IOPD and LOPD respectively. ${ }^{46-54}$ On the other hand, older children 
and adults usually present with slowly progressive limb girdle weakness, respiratory deterioration, rigid spine syndrome, scoliosis and low body mass. ${ }^{53,56} \mathrm{~A}$ growing number of large series of patients with LOPD had been described in the literature and were reviewed recently. ${ }^{57-64}$ As a result, the clinical presentation in LOPD has been expanded to include: ptosis, bulbar palsy and urinary incontinence. Taken together, the pathologic accumulation of glycogen in several tissues identified on autopsy examination and clinical experience with patients with Pompe disease revealed the following clinical correlations: diaphragm and intercostal muscles - respiratory failure, proximal skeletal muscle - progressive limb-girdle myopathy, genioglossus - tongue weakness, extraocular muscles - unilateral or bilateral ptosis, smooth muscle - abdominal pain/nausea/vomiting/diarrhea/urinary incontinence, and cerebral vasculature - cerebral aneurysm. ${ }^{65,66}$ However, the following associations do not seem to have clinical correlates: broadened cerebral gyri, increased number of cerebral and cerebellar astrocytes, lipofuscin deposits in neurons and astrocytes of the spinal cord and cerebellum, fibrillary gliosis and anterior horn cell degeneration, and glycogen vacuoles in the Schwann cells surrounding myelinated and unmyelinated axons of peripheral nerves.

\section{Pathogenesis of Pompe disease}

In Pompe disease, it is well established that the initial insult is due to the accumulation of the intra-lysosomal glycogen. However, recent studies showed that multiple other cellular abnormalities occur and that the pathophysiology of Pompe disease is far more complex than appreciated previously. In particular, the central role of autophagy is becoming more important now. ${ }^{67-78}$ Hers was the first to describe the histological features of autophagy which were then explicitly demonstrated using light and electron microscopic examination of skeletal muscle and confirmed by Engle and Dale ${ }^{4,77,78}$ Large pools of autophagic debris in skeletal muscle cells especially in type II fibers, were seen in both mouse Gaa knockout model and patients with Pompe disease. ${ }^{70-73}$ MAP1LC3, often referred to as LC3, and its membrane bound isoform (LC3-II) is commonly used as a specific marker of autophagosomes. ${ }^{76}$ Skin fibroblasts from patients with Pompe disease had been shown to have abnormal morphology with abnormal mannose-6-phosphate receptor trafficking which secondarily impaired rhGAA uptake in these cells. By electron microscopy, various features of enhanced autophagy such as the accumulation of multi-vesicular bodies, expansion of Golgi apparatus, abnormal intracellular distribution of CI-MPR and reduced availability of the receptor at the plasma membrane were identified. These abnormalities resulted in less efficient rhGAA uptake, processing and correction. ${ }^{71}$ Accumulation of autophagosomes is a key pathological finding in skeletal muscle fibers and skin fibroblasts from patients with Pompe disease and is implicated in the poor response to ERT. ${ }^{79}$ Mutant GAA initiates autophagy via the induction of endoplasmic reticulum (ER) stress as well as Akt inactivation (ER stress-independent) using mTOR suppression. Treatment with insulin which activates Akt signaling restored phosphorylation of both Akt and p70S6 kinase and suppressed autophagy in patient fibroblasts. Also, combination therapy using rhGAA and insulin enhanced correct co-localization of the enzyme with lysosomes. ${ }^{80}$ On the other hand, suppression of autophagy in the whole organism by knocking out critical autophagic genes (Atgs), such as Atg5 or Atg7 is lethal. ${ }^{74,75}$ 
Metabolic abnormalities in tissues and body fluids of GAA2/2 mice and humans respectively had also been identified. Abnormal glycogen metabolism (suppressed phosphorylase activity, elevated glycogen synthase, glycogenin, hexokinase activities, and glucose-6-phosphate) in the heart, skeletal muscles and liver from GAA2/2 mice was demonstrated. ${ }^{81,82}$ The effect of GAA deficiency in muscles of patients with Pompe disease extends to various vesicle systems linked to lysosomes including the early endosomes (rab5), recycling endosomes (transferrin receptor) and trans-Golgi network as they all showed increased immunoreactivity. ${ }^{83}$ Expression of the insulin responsive glucose transporter 4 was also markedly increased and partially co-localised with all vesicular markers, a phenomenon which may contribute to its abnormal homeostasis. In addition, abnormal energy metabolism, diminished plasma methylation capacity, elevated IGFBP1 and IGFBP-3 levels were found in patients with LOPD. ${ }^{84}$ Low carbohydrate and high protein-calorie diet was beneficial.

\section{Newborn Screening for Pompe disease}

Over several decades and since the inception of the universal newborn screening programs for inborn errors of metabolism, the number of disorders and the laboratory assays used to detect them continued to be limited. However, the introduction of tandem mass spectrometry in the late 1990's resulted in a significant and rapid expansion of the number of such disorders some of which may not fulfill the classical inclusion criteria of Wilson and Junger. ${ }^{85}$ Once again, tandem mass spectrometry based GAA enzyme activity assays had been shown recently to be potentially useful in newborn screening for Pompe disease and other lysosomal storage diseases using DBS [Table 5]. Newborn screening efforts for Pompe disease started in Taiwan since 2005. Recently, the United States Secretary's Discretionary Advisory Committee for Heritable Disorders in Newborns and Children recommended universal newborn screening for Pompe disease, an effort which started in some states based newborn screening laboratories. Few other newborn screening pilots were conducted in other countries around the world [Table 5] ${ }^{86-97}$ It is unclear how asymptomatic cases destined to have LOPD but detected on newborn screening should be followed and managed. ${ }^{64}$ While newborn screening for lysosomal storage diseases including Pompe disease is gaining acceptance, some investigators and ethicists recommended that screening for these conditions should only be performed in the research context with institutional review board approval and parental permission. ${ }^{98}$

\section{THE UNIVERSITY OF KANSAS MEDICAL CENTER CASE SERIES}

We performed a retrospective review of all patients diagnosed with infantile (IOPD) and late onset Pompe disease (LOPD) at the University of Kansas Medical Center between 2000 and 2013 (Tables 1-4). Muscle biopsies, GAA mutation analysis and GAA enzyme activity of muscle, skin fibroblasts, amniocytes and dried blood spots (DBS) were performed at various medical centers and reference clinical laboratories using standard techniques. Medline database was searched for reports of large series of patients with IOPD and LOPD, autopsies performed on patients with IOPD and LOPD and abortuses/abortions as well as those reports which describe new diagnostic techniques related to Pompe disease. 
We identified 3 patients with infantile (1 classical and 2 siblings with non-classical), and 9 patients with late onset (1 patient with juvenile and 8 with adult) Pompe disease. Male:female ratio was 1.4:1 and the average age of onset was 17.7 years (0-39). In this group, all 3 patients with infantile Pompe disease (cases 1,2,3) had varying degrees of hypertrophic cardiomyopathy which was most severe in patient 3 . Unlike patients 1 and 2 (Fig.3A, B), patient 3 (Fig.3C) appears to have classical Pompe disease with severe hypotonia and minimal strength in the upper and lower limbs. Overall, the presenting symptom was limb girdle weakness in $43 \%$ while $25 \%$ presented with shortness of breath and $17 \%$ had myalgia. Delay from first symptom to diagnosis was 6 years (1-22). In LOPD cases, shortness of breath affected 3/7 cases, presenting within 1-2 years of the first symptoms. Besides limb weakness, scapular winging was evident on presentation in $8 \%$ and 4/7 (57\%) had Trendelenburg gait. Low back pain was reported in 1 LOPD patient (12) in whom back surgery was done. MRI examination showed lower limb muscle fatty infiltration and edema (patient 4) and dilated cerebral -circle of Willis- vessels (patient 8).

Echocardiography revealed septal hypertrophy in two patients, left ventricular hypertrophy (LVH) in one patient and hypertrophic cardiomyopathy (HCM) in the child with classical IOPD. Urinary tetrasaccharide (Hex4) level was elevated in two patients $(3,8)$ and normal in three other patients with $\operatorname{LOPD}(4,7,9)$. Creatine kinase level ranged from 59 to 1,684 IU/L (mean 878) and electromyography showed evidence of myotonia in one out of four studied patients, with fibrillation and myopathic motor unit action potential (MUAP) present in this and another patient (6 and 7). The other 2 cases were either normal (episodic severe myalgia) or revealed myopathic MUAPs. DBS-GAA enzyme activity was less than $40 \%$ of the lower normal limit (10 pmol/punch/hour) in 7/9 patients and in the other 2 was in the borderline range of 40 to $50 \%$ of normal lower limit.

Most patients (8/12) had muscle biopsy as their first test followed by DBS-GAA activity level as a confirmatory test. Out of three IOPD cases, two underwent muscle biopsy; Case 2 showed vacuoles and microaggregates of glycogen on PAS confirmed to consist of abundant membrane bound glycogen on ultrastructural analysis (and markedly reduced muscle GAA enzyme activity) and Case 3 had vacuoles in 50\% of muscle fibers and accumulation of glycogen in less vacuolated fibers that was also seen in smooth muscle fibers of erector pili muscles on skin biopsy. Altogether all 9 LOPD cases underwent muscle biopsy except for Case 5, 7/8 muscle biopsies were suspicious for Pompe disease and the eighth biopsy showed nonspecific myopathic changes. Vacuoles were seen in 5 LOPD cases along with abnormal glycogen deposition on Periodic Acid Schiff (PAS) stain while the other 2 cases showed abnormal glycogen deposition without vacuolation. Hematoxilin and eosin stained muscle tissue showed rimmed vacuoles in 2 cases and non-rimmed in an additional 2cases. In one of these cases, rimmed vacuoles could not be confirmed on modified Gomori trichrome stain, but in Case 4 (severe episodic myalgia), there were non-rimmed vacuoles only seen on trichrome. Acid phosphatase positive vacuolar aggregates were seen in 2/5vacuolated muscle biopsies. Abnormal glycogen deposition on PAS was present in 7 cases and was the only finding in 2/7 biopsies suggestive of Pompe.

Ten patients received ERT and reported subjective improvement although this was not measurable on clinical examination except in case 2 with non-classical IOPD (see below) and case 9 where objective improvement in proximal arm strength was noted 4 months after 
the start of ERT. Anti-rhGAA antibody titers were elevated in 6 patients and negative in 2 patients (Table 4). In this cohort, all patients are still alive except patient 11 who was intolerant of ERT and died at 53 years of age due to progressive and severe respiratory insufficiency. GAA mutation analysis was done in 8/12 patients and a total of 12 mutations and 4 variants of unknown significance (VUS) were identified. All patients with identifiable mutations were compound heterozygotes except case 3 with classical IOPD who was "c. $1843 \mathrm{G}>\mathrm{A}$; p.Gly615Arg " homozygote. Two unrelated patients were heterozygous for the common "IVS1-13T $>$ G/c.-32-13t>g" mutation. The novel (heterozygous) mutation (c.-1402A $>$ T p.I468F) was identified in 2 unrelated patients while another novel splice site (c.546G >A) mutation was found in case 6 . Both novel alleles are predicted in-solico to be pathogenic. In this series, family history was positive in $3 \mathrm{sib}$ pairs (1 and 2; 5 and 6;10 and 11). Next, we describe 4 cases in this cohort in more details.

Patients 1 and 2 (Fig. 2A, B) are African American sib pair. The older brother was diagnosed with hypertrophic cardiomyopathy at 2 months of age when he was also found to be carnitine deficient. Cardiomyopathy did not resolve despite carnitine supplementation. At 5 years of age, he presented with skeletal muscle weakness and respiratory failure triggered by influenza pneumonia for which a tracheostomy was placed. He then became ventilator dependent. Membrane bound glycogen was abundant on muscle biopsy and muscle and DBS GAA enzyme activity were markedly reduced. About 18 months following the initiation of ERT, daytime ventilation was discontinued and muscle strength improved significantly. His younger sister was diagnosed prenatally with infantile Pompe disease via amniocentesis. GAA activity in amniocytes was undetectable. However, postnatal GAA activity in DBS was detectable but reduced. She had mild macroglossia (Fig. 2B) and her echocardiogram showed septal hypertrophy only. She is doing quite well despite the delay in starting her enzyme replacement therapy at 10 months of age. Both siblings maintain negative anti-rhGAA antibody titer. CRIM status was not tested in either sib since they had significant residual GAA activity and by definition would be CRIM positive.

Patient 3 is 8.5 year old Vietnamese boy (Fig.1A) with severe, classical, infantile Pompe disease and severe hypertrophic cardiomyopathy. His diagnosis was made at 4 months of age and received ERT almost immediately. Cross Reactive Immunologic Material (CRIM) testing of his skin fibroblasts by Western blot analysis was positive (Duke University). He continues to be ventilator dependent with minimal muscle power in both upper and lower limbs. He maintained a negative anti-rhGAA antibody titer until 1 year ago when he developed a non-neutralizing low titer at 1:200.

Patient 4 had a muscle biopsy at 10 years of age when she presented with severe recurrent myalgia. A provisional diagnosis of "atypical" dermatomyositis was made for which she was treated with steroids and hydroxychloroquine. Numerous other laboratory studies were uninformative. A second muscle biopsy was done at 18 years of age and showed membrane bound glycogen. Low GAA enzyme activity was detected in muscle tissue and skin fibroblasts while DBS GAA activity was borderline reduced at 4.8 (normal 10-49). Only one predicted to be pathogenic novel GAA mutation (c.1402A>T; p.I468F) was identified. Deletion/duplication analysis using exon array (GeneDx, Gaithersburg, MD) was negative as well. 
Case 7 presented as a young adult with progressive skeletal muscle weakness. The diagnosis of Pompe disease was made based on abnormal findings in muscle biopsy. GAA activity in DBS was low and GAA mutation analysis revealed compound heterozygosity for the common mutation (IVS1-13T>G) and a novel, likely deleterious, variant (p.R527F). She became pregnant for the first time while she was receiving alglucosidase alfa. She suffered a spontaneous miscarriage at 10 weeks gestation. Unfortunately, no pathological examination of the abortus was done.

\section{Discussion, Current Management and Therapeutic Options}

Our clinical experience with the 12 patients with Pompe disease which we report here is consistent with the literature. Findings in our case series suggest that a short latency between muscle symptoms and shortness of air should raise suspicion for LOPD. Muscle biopsy histopathology was done in 10/12 cases and was the first test to yield suspicion for Pompe disease in 8/12 cases and the second test in 2 out of the 4 remaining cases. DBS GAA enzymatic activity was done in $9 / 12$ cases, being the first test in 2 cases, the second confirmatory test in 6 cases (in 5/6 after muscle biopsy) and the third test in Case 4 following skin fibroblasts and muscle GAA analysis. Our only patient with classic IOPD who was CRIM positive still has profound muscle weakness and hypotonia despite early and adequate ERT and a very low non-neutralizing anti-rhGAA antibody titer which suggests another mechanism for his suboptimal clinical response. Case 11, an adult with LOPD, died due to progressive respiratory failure which was associated with a high anti-rhGAA antibody titer, an experience consistent with what Patel et al reported recently. ${ }^{99}$ Our 26year old Caucasian female (case 7) who became pregnant for the first time while receiving alglucosidase alfa had a serious adverse event as she suffered a spontaneous miscarriage at 14 weeks gestation. Unfortunately, we did not have access to the product of conception and therefore we were unable to determine the genotype. Her fetus may or may not have been affected with Pompe disease. While recombinant enzyme replacement therapy is generally thought to be safe during pregnancy, a possible direct/indirect detrimental effect on that pregnancy could not be excluded. In addition, the maternal anti-rhGAA antibodies may have played a role as well. While high sustained antibody titers in infantile and more recently late-onset Pompe disease correlate with poor outcome, their potential effect in pregnancy had not be reported yet. ${ }^{99}$ On the other hand, there are only two reports in the literature which describe a normal outcome in 2 babies whose mothers with Pompe disease were successfully and safely treated with alglucosidase alfa throughout their pregnancies. ${ }^{100,101}$ More clinical experience with the prenatal use of alglucosidase alfa is needed to establish its safety.

Since the recognition that maltose and acarbose inhibit neutral a-glucosidase activity, reliable measurement of acid GAA activity in DBS became feasible and was quickly adopted as a non-invasive alternative to skin fibroblasts and muscle biopsies which are invasive, more expensive and take longer time to process. Preisler et al used this approach to identify three patients with LOPD among 38 patients with unclassified LGMD (8\%). ${ }^{15}$ Also, as newborn screening for metabolic disorders utilizes blood collected on dried filter papers (DBS), various platforms to measure GAA activity in DBS were developed. They include: tandem mass spectrometry, fluorometric and microfluidics based enzyme assays (Table 5). 
Emerging evidence from these studies suggests a higher incidence of Pompe disease $(1 / 28,000)$ compared to lower estimates reported previously. In addition, GAA pseudodeficiency ( $<1 \%$ in Caucasians and up to $3.9 \%$ in Asians) was recognized which prompted an adjustment of the newborn screening algorithms. ${ }^{37}$

Based on a pooling of clinical studies, $28 \%$ of Pompe disease cases are infantile-onset, of which about $85 \%$ are classic infantile-onset and $75 \%$ of those are CRIM positive. ${ }^{30,103,104}$ CRIM negative patients with classic IOPD very likely will develop neutralizing antibodies upon exposure to rhGAA. Such antibodies limit the efficacy of ERT. Induction of immune tolerance using various regimens such as rituximab with plasma exchange or alternatively the combination of rituximab and methotrexate with or without intravenous gamma-globulin is an important therapeutic intervention which should be accomplished prior to initiation of ERT in such naïve patients. ${ }^{102-106}$ The recent development of a blood-based assay for determining CRIM status is expected to facilitate this process in a timely manner.

The growing literature on Pompe disease reveales significant clinical variability in the age of onset of symptoms among patients with late-onset Pompe disease which can be only partially predicted by their GAA genotype. Recently, expert opinion based guidelines about newborn screening, confirmatory and symptomatic diagnostic testing as well as management of patients with Pompe disease had been published. ${ }^{7,107}$ International Pompe disease registry (https://www.registrynxt.com/Pompe/) as well as country based registries had been established. ${ }^{87-92}$ Recent reports from these registries indicate that diagnostic delay for patients with Pompe disease is still significant, less than $2 / 3$ of muscle biopsies done in French patients showed specific features of Pompe disease thus confirming the importance of GAA enzymatic assessment, and high prevalence of scoliosis (33\%) especially among patients with IOPD. ${ }^{109,110,113}$ Systematic analysis of data collected from the Pompe Registry will help improve recognition of the disease, enhance understanding of its variable course and the effect of direct interventions such as current ERT and other potential future therapies.

The literature contains 29 autopsy examination reports of Pompe patients including 9 in the non-English literature and 8 reports of autopsies of fetuses affected with Pompe disease. Collectively, these studies demonstrated the extensive and generalized accumulation of lysosmal glycogen in various organs including the brain, well beyond the liver, heart and skeletal muscles. In the brain, the cytoplasm of Schwann cells but not neurons was shown to accumulate glycogen. This observation suggests that progressive neurodegeneration of the brain is not expected. While glycogen deposition was also demonstrated in the spinal cord and peripheral nerves, there is no clinical correlate to this finding since peripheral neuropathy had not been demonstrated clinically, by electromyography or by histologic examination of muscle. These observations are consistent with the report of better than expected cognitive outcomes in a small group of 10 children with classic infantile Pompe disease treated with alglucosidase alfa. They were evaluated prospectively both developmentally and by neuroimaging. ${ }^{114}$ Cognitive development at school age improved and ranged between normal and mildly delayed. Periventricular white matter abnormalities were found in 4 children. While treatment with alglucosidase alfa had been demonstrated to significantly increase survival in patients with IOPD, and since Pompe disease affects many 
tissues, including the brain, rhGAA is not expected to have beneficial effects on the central nervous system since it does not cross the blood-brain barrier.

The new insights into the complex pathogenesis of Pompe disease explain, at least partially, the suboptimal clinical response in patients with LOPD and some patients with IOPD. As a result, novel therapies including modified ERT are being investigated. Novel experimental modified rhGAA therapies include glycosylation-independent lysosomal targeting of GAA (rhGAA-GILT), ICAM-1-targeted nanocarriers which aim to enhance delivery of aglucosidase and muscle glycogen clearance, and neo-GAA. ${ }^{15-117}$ The neo-rhGAA is a carbohydrate-remodeled enzyme with higher affinity for the cation-independent mannose 6phosphate receptor and improved delivery to muscles of Pompe mice. Since CRIM negative IOPD patients are likely to develop neutralizing anti-rhGAA antibodies, early identification of their CRIM status and initiation of immunomodulation tolerance therapy using various approaches are very important for these patients. Co-administration of the pharmacologic chaperone, Duvoglustat hydrochloride (AT2220), with alglucosidase alfa in Pompe disease fibroblasts, blood cell lines and in-vivo appears to stabilize the enzyme and enhance its activity. ${ }^{117-119}$ A bacterial glycosidase which enables mannose-6-phosphate modification also improves cellular uptake of yeast-produced recombinant human lysosomal enzymes. ${ }^{120}$

Additional potentially promising investigational therapeutic approaches include: autophagy suppression, gene therapy using modified single-stranded oligonucleotides, short hairpin ribonucleic acids (shRNA), transcription factors (TFEB), AAV1-CMV-hGAA, hematopoietic stem cell (HSC) transplantation and induced pluripotent stem cells (iPS). ${ }^{120-134}$ GILT-tagged rhGAA (BMN 701), Duvoglustat hydrochloride (AT2220), neorhGAA and AAV1-CMV-hGAA are currently in clinical trials.

\section{Conclusion and Future Directions}

Pompe disease is the first metabolic myopathy for which corrective targeted enzyme replacement therapy was developed. Besides limb-girdle weakness and scoliosis in LOPD cases, shortness of air affected nearly half of our cases and led to early presentation within the first 2 years of symptom onset. The most common first diagnostic test to raise Pompe suspicion was muscle biopsy and confirmation was often with DBS assay. DBS GAA enzymatic activity levels in the borderline 40 to $50 \%$ range warrants further investigation. The efficacy of the current form of ERT is generally variable and unpredictable especially in patients with LOPD given the long diagnostic delay. There is a need for improved early recognition and therapy for this disorder which will be aided by improved understanding of its pathogenesis. Novel therapies based on improved understanding of the disease pathogenesis are already under study and some are in clinical trials. Early identification through newborn screening and more effective and specific therapies will likely significantly improve the outcome for all patients with Pompe disease.

\section{Acknowledgments}

The authors would like to thank all of our patients and their families for their kind support and interest in this study. We also thank Dawn Lockhart and all of the staff of the Clinical Trials Unit at the University of Kansas Medical Center for providing exemplary care for the patients and their families. 
This project was supported by an Institutional Clinical and Translational Science Award, NIH/NCATS Grant Number UL1TR000001. Its contents are solely the responsibility of the authors and do not necessarily represent the official views of the NIH.

\section{References}

1. Pompe JC. Over idiopatische hypertrophie van het hart. Ned Tijdschr Geneeskd. 1932; 76:304-12.

2. Bischoff G. Zum klinischen Bild der Glykogen-Speicherungs-Krankheit (Glykogenose). Zeitschrift fu Kinderheilkunde. 1932; 52:722-5.

3. Putschar M. Uber angeborene Glykogenspeicher-Krankheit des herzens. "Thesaurismosis glycogenica" (v. Gierke). Beitr Pathol Anat Allg Pathol. 1932; 90:222-31.

4. Hers HG. alpha-Glucosidase deficiency in generalized glycogenstorage disease (Pompe's disease). Biochem J. 1963; 86:11-6. [PubMed: 13954110]

5. van den Hout HM, Hop W, van Diggelen OP, et al. The natural course of infantile Pompe's disease: 20 original cases compared with 133 cases from the literature. Pediatrics. 2003; 112:332-40. [PubMed: 12897283]

6. Case LE, Beckemeyer AA, Kishnani PS. Infantile Pompe disease on ERT: update on clinical presentation, musculoskeletal management, and exercise considerations. Am J Med Genet C Semin Med Genet. 2012; 160C:69-79. [PubMed: 22252989]

7. Cupler EJ, Berger KI, Leshner RT, et al. Consensus treatment recommendations for late-onset Pompe disease. Muscle Nerve. 2012; 45:319-33. [PubMed: 22173792]

8. Levine B, Klionsky DJ. Development by self-digestion: molecular mechanisms and biological functions of autophagy. Dev Cell. 2004; 6:463-77. [PubMed: 15068787]

9. Levine B, Deretic V. Unveiling the roles of autophagy in innate and adaptive immunity. Nat Rev Immunol. 2007; 7:767-77. [PubMed: 17767194]

10. Eng CH, Yu K, Lucas J, et al. Ammonia derived from glutaminolysis is a diffusible regulator of autophagy. Sci Signal. 2010; 3:ra31. [PubMed: 20424262]

11. Shintani T, Klionsky DJ. Autophagy in health and disease: a double-edged sword. Science. 2004; 306:990-5. [PubMed: 15528435]

12. Huang J, Klionsky DJ. Autophagy and human disease. Cell Cycle. 2007; 6:1837-49. [PubMed: 17671424]

13. Mizushima N, Levine B, Cuervo AM, et al. Autophagy fights disease through cellular selfdigestion. Nature. 2008; 451:1069-75. [PubMed: 18305538]

14. Nixon RA. The role of autophagy in neurodegenerative disease. Nat Med. 2013; 19:983-97. [PubMed: 23921753]

15. Preisler N, Lukacs Z, Vinge L, et al. Late-onset Pompe disease is prevalent in unclassified limbgirdle muscular dystrophies. Mol Genet Metab. 2013; 110:287-9. [PubMed: 24011652]

16. Schüller A, Wenninger S, Strigl-Pill N, Schoser B. Toward deconstructing the phenotype of lateonset Pompe disease. Am J Med Genet C Semin Med Genet. 2012; 160:80-8. [PubMed: 22253010]

17. Meikle PJ, Yan M, Ravenscroft EM, Isaac EL, Hopwood JJ, Brooks DA. Altered trafficking and turnover of LAMP-1 in Pompe disease-affected cells. Mol Genet Metab. 1999; 66:179-88. [PubMed: 10066386]

18. Platt FM, Boland B, van der Spoel AC. The cell biology of disease: lysosomal storage disorders: the cellular impact of lysosomal dysfunction. J Cell Biol. 2012; 199:723-34. [PubMed: 23185029]

19. Kornfeld S. Trafficking of lysosomal enzymes in normal and disease states. J Clin Invest. 1986; 77:1-6. [PubMed: 3003148]

20. Wisselaar HA, Kroos MA, Hermans MM, et al. Structural and functional changes of lysosomal acid alpha-glucosidase during intracellular transport and maturation. J Biol Chem. 1993; 268:2223-31. [PubMed: 8420990]

21. Chamoles NA, Niizawa G, Blanco M, et al. Glycogen storage disease type II: enzymatic screening in dried blood spots on filter paper. Clin Chim Acta. 2004; 347:97-102. [PubMed: 15313146]

22. Niizawa G, Levin C, Aranda C, et al. Retrospective diagnosis of glycogen storage disease type II by use of a newborn-screening card. Clin Chim Acta. 2005; 359:205-6. [PubMed: 15963968] 
23. Zhang H, Kallwass H, Young SP, et al. Comparison of maltose and acarbose as inhibitors of maltase-glucoamylase activity in assaying acid alpha-glucosidase activity in dried blood spots for the diagnosis of infantile Pompe disease. Genet Med. 2006; 8:302-6. [PubMed: 16702880]

24. Sista RS, Wang T, Wu N, et al. Multiplex newborn screening for Pompe, Fabry, Hunter, Gaucher, and Hurler diseases using a digital microfluidic platform. Clin Chim Acta. 2013; 424:12-8. [PubMed: 23660237]

25. Metz TF, Mechtler TP, Orsini JJ, et al. Simplified newborn screening protocol for lysosomal storage disorders. Clin Chem. 2011; 57:1286-94. [PubMed: 21771947]

26. Spáčil Z, Elliott S, Reeber SL, et al. Comparative triplex tandem mass spectrometry assays of lysosomal enzyme activities in dried blood spots using fast liquid chromatography: application to newborn screening of Pompe, Fabry, and Hurler diseases. Anal Chem. 2011; 83:4822-8. [PubMed: 21548611]

27. Mechtler TP, Metz TF, Müller HG, et al. Short-incubation mass spectrometry assay for lysosomal storage disorders in newborn and high-risk population screening. J Chromatogr B Analyt Technol Biomed Life Sci. 2012; 908:9-17.

28. Young SP, Piraud M, Goldstein JL, et al. Assessing disease severity in Pompe disease: the roles of a urinary glucose tetrasaccharide biomarker and imaging techniques. Am J Med Genet C Semin Med Genet. 2012; 160C:50-8. [PubMed: 22252961]

29. Xia B, Asif G, Arthur L, et al. Oligosaccharide analysis in urine by maldi-tof mass spectrometry for the diagnosis of lysosomal storage diseases. Clin Chem. 2013; 59:1357-68. [PubMed: 23676310]

30. Wang Z, Okamoto P, Keutzer J. A new assay for fast, reliable CRIM status determination in infantile-onset Pompe disease. Mol Genet Metab. 2014; 111:92-100. [PubMed: 24044919]

31. Van Hove JL, Yang HW, Wu JY, et al. High-level production of recombinant human lysosomal acid alpha-glucosidase in Chinese hamster ovary cells which targets to heart muscle and corrects glycogen accumulation in fibroblasts from patients with Pompe disease. Proc Natl Acad Sci U S A. 1996; 93:65-70. [PubMed: 8552676]

32. Nascimbeni AC, Fanin M, Tasca E, Angelini C. Molecular pathology and enzyme processing in various phenotypes of acid maltase deficiency. Neurology. 2008; 70:617-26. [PubMed: 18285536]

33. Sugawara K, Saito S, Sekijima M, et al. Structural modeling of mutant alpha-glucosidases resulting in a processing/transport defect in Pompe disease. J Hum Genet. 2009; 54:324-30. [PubMed: 19343043]

34. Kroos MA, Mullaart RA, Van Vliet L, et al. p.[G576S; E689K]: pathogenic combination or polymorphism in Pompe disease? Eur J Hum Genet. 2008; 16:875-9. [PubMed: 18301443]

35. Tajima Y, Matsuzawa F, Aikawa S, et al. Structural and biochemical studies on Pompe disease and a "pseudodeficiency of acid alpha-glucosidase". J Hum Genet. 2007; 52:898-906. [PubMed: 17805474]

36. Kumamoto S, Katafuchi T, Nakamura K, et al. High frequency of acid alpha-glucosidase pseudodeficiency complicates newborn screening for glycogen storage disease type II in the Japanese population. Mol Genet Metab. 2009; 97:190-5. [PubMed: 19362502]

37. Labrousse P, Chien YH, Pomponio RJ, et al. Genetic heterozygosity and pseudodeficiency in the Pompe disease newborn screening pilot program. Mol Genet Metab. 2010; 99:379-83. [PubMed: 20080426]

38. Costin-Kelly N. The Biomedical Scientist. 2008:1063-70.

39. Werneck LC, Lorenzoni PJ, Kay CS, et al. Muscle biopsy in Pompe disease. Arq Neuropsiquiatr. 2013; 71:284-9. [PubMed: 23689405]

40. Vissing J, Lukacs Z, Straub V. Diagnosis of Pompe disease: muscle biopsy vs blood-based assays. JAMA Neurol. 2013; 70:923-7. [PubMed: 23649721]

41. Winkel LP, Kamphoven JH, van den Hout HJ, et al. Morphological changes in muscle tissue of patients with infantile Pompe's disease receiving enzyme replacement therapy. Muscle Nerve. 2003; 27:743-51. [PubMed: 12766987]

42. Prater SN, Patel TT, Buckley AF, et al. Skeletal muscle pathology of infantile Pompe disease during long-term enzyme replacement therapy. Orphanet J Rare Dis. 2013; 8:90. [PubMed: 23787031] 
43. Al-Lozi MT, Amato AA, Barohn RJ, et al. American Association of Neuromuscular \& Electrodiagnostic Medicine. Diagnostic criteria for late-onset (childhood and adult) Pompe disease. Muscle Nerve. 2009; 40:149-60. [PubMed: 19533647]

44. van der Beek NA, de Vries JM, Hagemans ML, et al. Clinical features and predictors for disease natural progression in adults with Pompe disease: a nationwide prospective observational study. Orphanet J Rare Dis. 2012; 7:88. [PubMed: 23147228]

45. Hobson-Webb LD, Jones HN, Kishnani PS. Oropharyngeal dysphagia may occur in late-onset Pompe disease, implicating bulbar muscle involvement. Neuromuscul Disord. 2013; 23:319-23. [PubMed: 23332114]

46. Bruni CB, Paluello FM. A biochemical and ultrastructural study of liver, muscle, heart and kidney in type II glycogenosis. Virchows Arch B Cell Pathol. 1970; 4:196-207. [PubMed: 4983073]

47. Libert J, Martin JJ, Ceuterick C, Danis P. Ocular ultrastructural study in a fetus with type II glycogenosis. Br J Ophthalmol. 1977; 61:476-82. [PubMed: 268211]

48. Nakamura Y, Tanimura A, Yasuoka C, Kato H. An autopsy case of type II glycogenosis. Kurume Med J. 1979; 26:349-54. [PubMed: 296782]

49. Pokorny KS, Ritch R, Friedman AH, Desnick RJ. Ultrastructure of the eye in fetal type II glycogenosis (Pompe's disease). Invest Ophthalmol Vis Sci. 1982; 22:25-31. [PubMed: 6948796]

50. Margolis ML, Howlett P, Goldberg R, Eftychiadis A, Levine S. Obstructive sleep apnea syndrome in acid maltase deficiency. Chest. 1994; 105:947-9. [PubMed: 8131573]

51. Teng YT, Su WJ, Hou JW, Huang SF. Infantile-onset glycogen storage disease type II (Pompe disease): report of a case with genetic diagnosis and pathological findings. Chang Gung Med J. 2004; 27:379-84. [PubMed: 15366815]

52. Phupong V, Shuangshoti S, Sutthiruangwong P, Maneesri S, Nuayboonma P, Shotelersuk V. Prenatal diagnosis of Pompe disease by electron microscopy. Arch Gynecol Obstet. 2005; 271:259-61. [PubMed: 15146345]

53. Kobayashi H, Shimada Y, Ikegami M, et al. Prognostic factors for the late onset Pompe disease with enzyme replacement therapy: from our experience of 4 cases including an autopsy case. Mol Genet Metab. 2010; 100:14-9. [PubMed: 20202878]

54. Hobson-Webb LD, Proia AD, Thurberg BL, et al. Autopsy findings in late-onset Pompe disease: a case report and systematic review of the literature. Mol Genet Metab. 2012; 106:462-9. [PubMed: 22664150]

55. Fuller DD, ElMallah MK, Smith BK, et al. The respiratory neuromuscular system in Pompe disease. Respir Physiol Neurobiol. 2013; 189:241-9. [PubMed: 23797185]

56. Zamanifekri B, Barohn RJ, Herbelin L, McVey AL, Pasnoor M, Dimachkie MM. Tongue Weakness in a patient with myopathy. J Clin Neuromusc Dis. 2013; 14-S1:19.

57. Güngör D, Kruijshaar ME, Plug I, et al. Impact of enzyme replacement therapy on survival in adults with Pompe disease: results from a prospective international observational study. Orphanet J Rare Dis. 2013; 8:49. [PubMed: 23531252]

58. van der Ploeg AT, Barohn R, Carlson L, et al. Open-label extension study following the LateOnset Treatment Study (LOTS) of alglucosidase alfa. Mol Genet Metab. 2012; 107:456-61. [PubMed: 23031366]

59. Papadimas GK, Spengos K, Konstantinopoulou A, et al. Adult Pompe disease: clinical manifestations and outcome of the first Greek patients receiving enzyme replacement therapy. Clin Neurol Neurosurg. 2011; 113:303-7. [PubMed: 21216089]

60. Herzog A, Hartung R, Reuser AJ, et al. A cross-sectional single-centre study on the spectrum of Pompe disease, German patients: molecular analysis of the GAA gene, manifestation and genotype-phenotype correlations. Orphanet J Rare Dis. 2012; 7:35. [PubMed: 22676651]

61. Güngör D, de Vries JM, Brusse E, et al. Enzyme replacement therapy and fatigue in adults with Pompe disease. Mol Genet Metab. 2013; 109:174-8. [PubMed: 23603069]

62. Angelini C, Semplicini C. Enzyme replacement therapy for Pompe disease. Curr Neurol Neurosci Rep. 2012; 12:70-5. [PubMed: 22002767]

63. Toscano A, Schoser B. Enzyme replacement therapy in late-onset Pompe disease: a systematic literature review. J Neurol. 2013; 260:951-9. [PubMed: 22926164] 
64. Chien YH, Hwu WL, Lee NC. Pompe disease: early diagnosis and early treatment make a difference. Pediatr Neonatol. 2013; 54:219-27. [PubMed: 23632029]

65. Patel TT, Banugaria SG, Frush DP, et al. Basilar artery aneurysm: a new finding in classic infantile Pompe disease. Muscle Nerve. 2013; 47:613-5. [PubMed: 23401069]

66. El-Gharbawy AH, Bhat G, Murillo JE, et al. Expanding the clinical spectrum of late-onset Pompe disease: dilated arteriopathy involving the thoracic aorta, a novel vascular phenotype uncovered. Mol Genet Metab. 2011; 103:362-6. [PubMed: 21605996]

67. DiMauro S, Spiegel R. Progress and problems in muscle glycogenoses. Acta Myol. 2011; 30:96102. [PubMed: 22106711]

68. Oldfors A, DiMauro S. New insights in the field of muscle glycogenoses. Curr Opin Neurol. 2013; 26:544-53. [PubMed: 23995275]

69. Malicdan MC, Nishino I. Autophagy in lysosomal myopathies. Brain Pathol. 2012; 22:82-8. [PubMed: 22150923]

70. Raben N, Wong A, Ralston E, et al. Autophagy and mitochondria in Pompe disease: nothing is so new as what has long been forgotten. Am J Med Genet C Semin Med Genet. 2012; 160C:13-21. [PubMed: 22253254]

71. Cardone M, Porto C, Tarallo A, et al. Abnormal mannose-6-phosphate receptor trafficking impairs recombinant alpha-glucosidase uptake in Pompe disease fibroblasts. Pathogenetics. 2008; 1:6. [PubMed: 19046416]

72. Fukuda T, Ewan L, Bauer M, et al. Dysfunction of endocytic and autophagic pathways in a lysosomal storage disease. Ann Neurol. 2006; 59:700-8. [PubMed: 16532490]

73. Seppälä EH, Reuser AJ, Lohi H. A nonsense mutation in the acid a-glucosidase gene causes Pompe disease in Finnish and Swedish Lapphunds. PLoS One. 2013; 8:e56825. [PubMed: 23457621]

74. Kuma A, Hatano M, Matsui M, et al. The role of autophagy during the early neonatal starvation period. Nature. 2004; 432:1032-6. [PubMed: 15525940]

75. Komatsu M, Waguri S, Ueno T, et al. Impairment of starvation-induced and constitutive autophagy in Atg7-deficient mice. J Cell Biol. 2005; 169:425-34. [PubMed: 15866887]

76. Kabeya Y, Mizushima N, Ueno T, et al. LC3, a mammalian homologue of yeast Apg8, is localized in autophagosome membranes after processing. EMBO J. 2000; 19:5720-8. [PubMed: 11060023]

77. Engel AG, Dale AJ. Autophagic glycogenosis of late onset with mitochondrial abnormalities: Light and electron microscopic observations. Mayo Clin Proc. 1968; 43:233-79. [PubMed: 4886322]

78. Engel AG. Acid maltase deficiency in adults: Studies in four cases of a syndrome which may mimic muscular dystrophy or other myopathies. Brain. 1970; 93:599-616. [PubMed: 4918728]

79. Nishiyama Y, Shimada Y, Yokoi T, et al. Suppression of autophagy in skeletal muscle uncovers the accumulation of ubiquitinated proteins and their potential role in muscle damage in Pompe disease. Hum Mol Genet. 2008; 17:3897-908. [PubMed: 18782848]

80. Nishiyama Y, Shimada Y, Yokoi T, et al. Akt inactivation induces endoplasmic reticulum stressindependent autophagy in fibroblasts from patients with Pompe disease. Mol Genet Metab. 2012; 107:490-5. [PubMed: 23041259]

81. Taylor KM, Meyers E, Phipps M, et al. Dysregulation of multiple facets of glycogen metabolism in a murine model of Pompe disease. PLoS One. 2013; 8:e56181. [PubMed: 23457523]

82. Raben N, Danon M, Gilbert AL, et al. Enzyme replacement therapy in the mouse model of Pompe disease. Mol Genet Metab. 2003; 80:159-69. [PubMed: 14567965]

83. Orth M, Mundegar RR. Effect of acid maltase deficiency on the endosomal/lysosomal system and glucose transporter 4. Neuromuscul Disord. 2003; 13:49-54. [PubMed: 12467732]

84. Pascual JM, Roe CR. Systemic metabolic abnormalities in adult-onset acid maltase deficiency: beyond muscle glycogen accumulation. JAMA Neurol. 2013; 70:756-63. [PubMed: 23609947]

85. Wilson, JMG.; Jungner, G. WHO Chronicle. Vol. 22. Geneva: World Health Organization; 1968. Principles and practice of screening for disease; p. 473

86. Scott CR, Elliott S, Buroker N, et al. Identification of infants at risk for developing Fabry, Pompe, or mucopolysaccharidosis-I from newborn blood spots by tandem mass spectrometry. J Pediatr. 2013; 163:498-503. [PubMed: 23465405] 
87. Orsini JJ, Martin MM, Showers AL, et al. Lysosomal storage disorder 4+1 multiplex assay for newborn screening using tandem mass spectrometry: application to a small-scale population study for five lysosomal storage disorders. Clin Chim Acta. 2012; 413:1270-3. [PubMed: 22548856]

88. Kemper, AR. The Condition Review Workgroup. EVIDENCE REPORT: NEWBORN SCREENING FOR POMPE DISEASE. Jun 3. 2013 (http://www.hrsa.gov/advisorycommittees/ mchbadvisory/heritabledisorders/nominatecondition/reviews/pompereport2013.pdf)

89. Burton BK. Newborn screening for Pompe disease: an update, 2011. Am J Med Genet C Semin Med Genet. 2012; 160C:8-12. [PubMed: 22253219]

90. Chien YH, Lee NC, Huang HJ, Thurberg BL, et al. Later-onset Pompe disease: early detection and early treatment initiation enabled by newborn screening. J Pediatr. 2011; 158:1023-7. [PubMed: 21232767]

91. Chiang SC, Hwu WL, Lee NC, et al. Algorithm for Pompe disease newborn screening: results from the Taiwan screening program. Mol Genet Metab. 2012; 106:281-6. [PubMed: 22578805]

92. Oda E, Tanaka T, Migita O, et al. Newborn screening for Pompe disease in Japan. Mol Genet Metab. 2011; 104:560-5. [PubMed: 21963784]

93. Paciotti S, Persichetti E, Pagliardini S, et al. First pilot newborn screening for four lysosomal storage diseases in an Italian region: identification and analysis of a putative causative mutation in the GBA gene. Clin Chim Acta. 2012; 413:1827-31. [PubMed: 22820396]

94. Wittmann J, Karg E, Turi S, et al. Newborn screening for lysosomal storage disorders in hungary. JIMD Rep. 2012; 6:117-25. [PubMed: 23430949]

95. Lukacs Z, Nieves Cobos P, Keil A, et al. Dried blood spots in the diagnosis of lysosomal storage disorders--possibilities for newborn screening and high-risk population screening. Clin Biochem. 2011; 44:476. [PubMed: 22036333]

96. Uribe A, Giugliani R. Selective screening for lysosomal storage diseases with dried blood spots collected on filter paper in 4,700 high-risk colombian subjects. JIMD Rep. 2013; 11:107-16. [PubMed: 23609959]

97. Mechtler TP, Stary S, Metz TF, et al. Neonatal screening for lysosomal storage disorders: feasibility and incidence from a nationwide study in Austria. Lancet. 2012; 379:335-41. [PubMed: 22133539]

98. Ross LF. Newborn screening for lysosomal storage diseases: an ethical and policy analysis. J Inherit Metab Dis. 2012; 35:627-34. [PubMed: 22189599]

99. Patel TT, Banugaria SG, Case LE, et al. The impact of antibodies in late-onset Pompe disease: a case series and literature review. Mol Genet Metab. 2012; 106:301-9. [PubMed: 22613277]

100. de Vries JM, Brugma JD, Ozkan L, et al. First experience with enzyme replacement therapy during pregnancy and lactation in Pompe disease. Mol Genet Metab. 2011; 104:552-5. [PubMed: 21967859]

101. Zagnoli F, Leblanc A, Blanchard C. Pregnancy during enzyme replacement therapy for late-onset acid maltase deficiency. Neuromuscul Disord. 2013; 23:180-1. [PubMed: 23290485]

102. Kishnani PS, Goldenberg PC, DeArmey SL, et al. Cross-reactive immunologic material status affects treatment outcomes in Pompe disease infants. Mol Genet Metab. 2010; 99:26-33. [PubMed: 19775921]

103. Messinger YH, Mendelsohn NJ, Rhead W, et al. Successful immune tolerance induction to enzyme replacement therapy in CRIM-negative infantile Pompe disease. Genet Med. 2012; 14:135-42. [PubMed: 22237443]

104. Banugaria SG, Prater SN, Patel TT, et al. Algorithm for the early diagnosis and treatment of patients with cross reactive immunologic material-negative classic infantile pompe disease: a step towards improving the efficacy of ERT. PLoS One. 2013; 8:e67052. [PubMed: 23825616]

105. Deodato F, Ginocchio VM, Onofri A, et al. Immune Tolerance Induced Using Plasma Exchange and Rituximab in an Infantile Pompe Disease Patient. J Child Neurol. 2013 Apr 25. Epub ahead of print.

106. Elder ME, Nayak S, Collins SW, et al. B-Cell depletion and immunomodulation before initiation of enzyme replacement therapy blocks the immune response to acid alpha-glucosidase in infantile-onset Pompe disease. J Pediatr. 2013; 163:847-54. [PubMed: 23601496] 
107. Wang RY, Bodamer OA, Watson MS, et al. Lysosomal storage diseases: diagnostic confirmation and management of presymptomatic individuals. Genet Med. 2011; 13:457-84. [PubMed: 21502868]

108. Byrne BJ, Kishnani PS, Case LE, et al. Pompe disease: design, methodology, and early findings from the Pompe Registry. Mol Genet Metab. 2011; 103:1-11. [PubMed: 21439876]

109. Roberts M, Kishnani PS, van der Ploeg AT, et al. The prevalence and impact of scoliosis in Pompe disease: lessons learned from the Pompe Registry. Mol Genet Metab. 2011; 104:574-82. [PubMed: 21930409]

110. Kishnani PS, Amartino HM, Lindberg C, et al. Timing of diagnosis of patients with Pompe disease: data from the Pompe registry. Am J Med Genet A. 2013; 161:2431-43. [PubMed: 23997011]

111. Martins AM, Kerstenezky M, Linares A, et al. Utility of rare disease registries in latin america. JIMD Rep. 2011; 1:111-5. [PubMed: 23430837]

112. Hundsberger T, Rohrbach M, Kern L, Rösler KM. Swiss national guideline for reimbursement of enzyme replacement therapy in late-onset Pompe disease. J Neurol. 2013; 260:2279-85. [PubMed: 23749294]

113. Laforêt P, Laloui K, Granger B, et al. The French Pompe registry. Baseline characteristics of a cohort of 126 patients with adult Pompe disease. Rev Neurol (Paris). 2013; 169:595-602. [PubMed: 24008051]

114. Ebbink BJ, Aarsen FK, van Gelder CM, et al. Cognitive outcome of patients with classic infantile Pompe disease receiving enzyme therapy. Neurology. 2012; 78:1512-8. [PubMed: 22539577]

115. Maga JA, Zhou J, Kambampati R, et al. Glycosylation-independent lysosomal targeting of acid aglucosidase enhances muscle glycogen clearance in pompe mice. J Biol Chem. 2013; 288:142838. [PubMed: 23188827]

116. Hsu J, Northrup L, Bhowmick T, et al. Enhanced delivery of a-glucosidase for Pompe disease by ICAM-1-targeted nanocarriers: comparative performance of a strategy for three distinct lysosomal storage disorders. Nanomedicine. 2012; 8:731-9. [PubMed: 21906578]

117. Zhu Y, Li X, McVie-Wylie A, et al. Carbohydrate-remodelled acid alpha-glucosidase with higher affinity for the cation-independent mannose 6-phosphate receptor demonstrates improved delivery to muscles of Pompe mice. Biochem J. 2005; 389:619-28. [PubMed: 15839836]

118. Khanna R, Flanagan JJ, Feng J, et al. The pharmacological chaperone AT2220 increases recombinant human acid a-glucosidase uptake and glycogen reduction in a mouse model of Pompe disease. PLoS One. 2012; 7:e40776. [PubMed: 22815812]

119. Flanagan JJ, Rossi B, Tang K, et al. The pharmacological chaperone 1-deoxynojirimycin increases the activity and lysosomal trafficking of multiple mutant forms of acid alphaglucosidase. Hum Mutat. 2009; 30:1683-92. [PubMed: 19862843]

120. Porto C, Cardone M, Fontana F, et al. The pharmacological chaperone N-butyldeoxynojirimycin enhances enzyme replacement therapy in Pompe disease fibroblasts. Mol Ther. 2009; 17:964-71. [PubMed: 19293774]

121. Tiels P, Baranova E, Piens K, et al. A bacterial glycosidase enables mannose-6-phosphate modification and improved cellular uptake of yeast-produced recombinant human lysosomal enzymes. Nat Biotechnol. 2012; 30:1225-31. [PubMed: 23159880]

122. Richard E, Douillard-Guilloux G, Caillaud C. New insights into therapeutic options for Pompe disease. IUBMB Life. 2011; 63:979-86. [PubMed: 22002928]

123. Raben N, Hill V, Shea L, et al. Suppression of autophagy in skeletal muscle uncovers the accumulation of ubiquitinated proteins and their potential role in muscle damage in Pompe disease. Hum Mol Genet. 2008; 17:3897-908. [PubMed: 18782848]

124. Raben N, Schreiner C, Baum R, et al. Suppression of autophagy permits successful enzyme replacement therapy in a lysosomal storage disorder--murine Pompe disease. Autophagy. 2010; 6:1078-89. [PubMed: 20861693]

125. Lu IL, Lin CY, Lin SB, et al. Correction/mutation of acid alpha-D-glucosidase gene by modified single-stranded oligonucleotides: in vitro and in vivo studies. Gene Ther. 2003; 10:1910-6. [PubMed: 14502220] 
126. Douillard-Guilloux G, Raben N, Takikita S, et al. Modulation of glycogen synthesis by RNA interference: towards a new therapeutic approach for glycogenosis type II. Hum Mol Genet. 2008; 17:3876-86. [PubMed: 18782850]

127. Feeney EJ, Spampanato C, Puertollano R, et al. What else is in store for autophagy? Exocytosis of autolysosomes as a mechanism of TFEB-mediated cellular clearance in Pompe disease. Autophagy. 2013; 9:1117-8. [PubMed: 23669057]

128. Spampanato C, Feeney E, Li L, Cardone M, et al. Transcription factor EB (TFEB) is a new therapeutic target for Pompe disease. EMBO Mol Med. 2013; 5:691-706. [PubMed: 23606558]

129. Byrne BJ, Falk DJ, Pacak CA, et al. Pompe disease gene therapy. Hum Mol Genet. 2011; 20:R61-8. [PubMed: 21518733]

130. Qiu K, Falk DJ, Reier PJ, et al. Spinal delivery of AAV vector restores enzyme activity and increases ventilation in Pompe mice. Mol Ther. 2012; 20:21-7. [PubMed: 22008916]

131. Conlon TJ, Erger K, Porvasnik S, et al. Preclinical toxicology and biodistribution studies of recombinant adeno-associated virus 1 human acid a-glucosidase. Hum Gene Ther Clin Dev. 2013; 24:127-33. [PubMed: 24021025]

132. Douillard-Guilloux G, Richard E, Batista L, et al. Partial phenotypic correction and immune tolerance induction to enzyme replacement therapy after hematopoietic stem cell gene transfer of alpha-glucosidase in Pompe disease. J Gene Med. 2009; 11:279-87. [PubMed: 19263466]

133. van Til NP, Stok M, Aerts Kaya FS, et al. Lentiviral gene therapy of murine hematopoietic stem cells ameliorates the Pompe disease phenotype. Blood. 2010; 115:5329-37. [PubMed: 20385789]

134. Kawagoe S, Higuchi T, Meng XL, et al. Generation of induced pluripotent stem (iPS) cells derived from a murine model of Pompe disease and differentiation of Pompe-iPS cells into skeletal muscle cells. Mol Genet Metab. 2011; 104:123-8. [PubMed: 21703893] 


\section{KEY POINTS}

- Pompe disease, also known as type II glycogenosis, is a progressive autosomal recessive glycogen storage disease caused by deficiency of lysosomal acid alpha glucosidase (GAA) primarily in skeletal and cardiac muscle with age of onset ranging from infancy through adulthood. Extramuscular phenotypes are also recognized.

- Recognized clinical presentations of Pompe disease include infantile (with/ without cardiomyopathy) and late onset (childhood, juvenile and adult) forms. In addition to cardiomyopathy in the classic infantile form, musculoskeletal signs and symptoms are the most frequent.

- Excessive lysosomal glycogen storage and defects in autophagy are the main determinants of pathogenesis of Pompe disease.

- Diagnosis of symptomatic individuals as well as screening in healthy newborns is now possible by demonstrating low GAA enzyme activity in dried blood samples complemented by DNA mutation analysis.

- Diagnostic gaps in Pompe disease patients across the disease spectrum continue.

- In our cohort of patients, 3 with infantile and 9 with late onset Pompe disease, we identified 4 novel, potentially pathogenic $G A A$ mutations and one pregnancy which was complicated by prenatal exposure to recombinant human rhGAA and spontaneous miscarriage.

- In addition to supportive therapy, rhGAA enzyme replacement therapy (ERT) is now available. Oral chaperone therapy, modified rhGAA, autophagy suppression and gene transfer represent potentially promising novel therapies that are being tested in clinical research trials. 


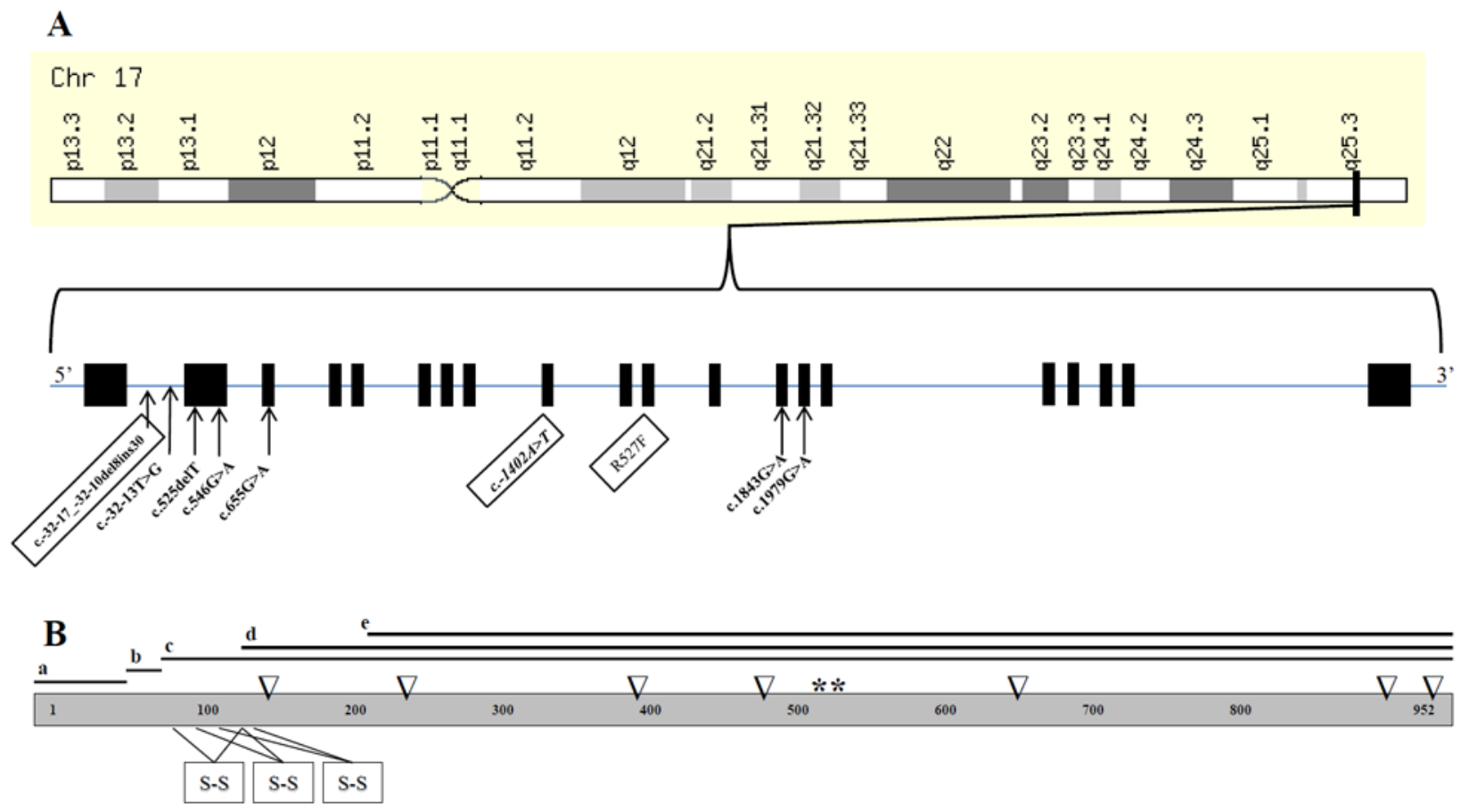

Figure 1.

Schematic representations of $G A A$ genomic location and structure (A) and its protein structure (B). GAA maps to chr17q25.3 and consists of 20 (19 coding) exons which encode 952 amino acids. Mutations (DNA variants) identified in this study are shown according to their respective genomic position. Novel variants are boxed. GAA has 4 isoforms (a-d), 2 catalytically active sites $(*), 3$ disulfide bonds (s-s) and $7 \mathrm{~N}$-linked glycosylation sites $(\nabla)$. 

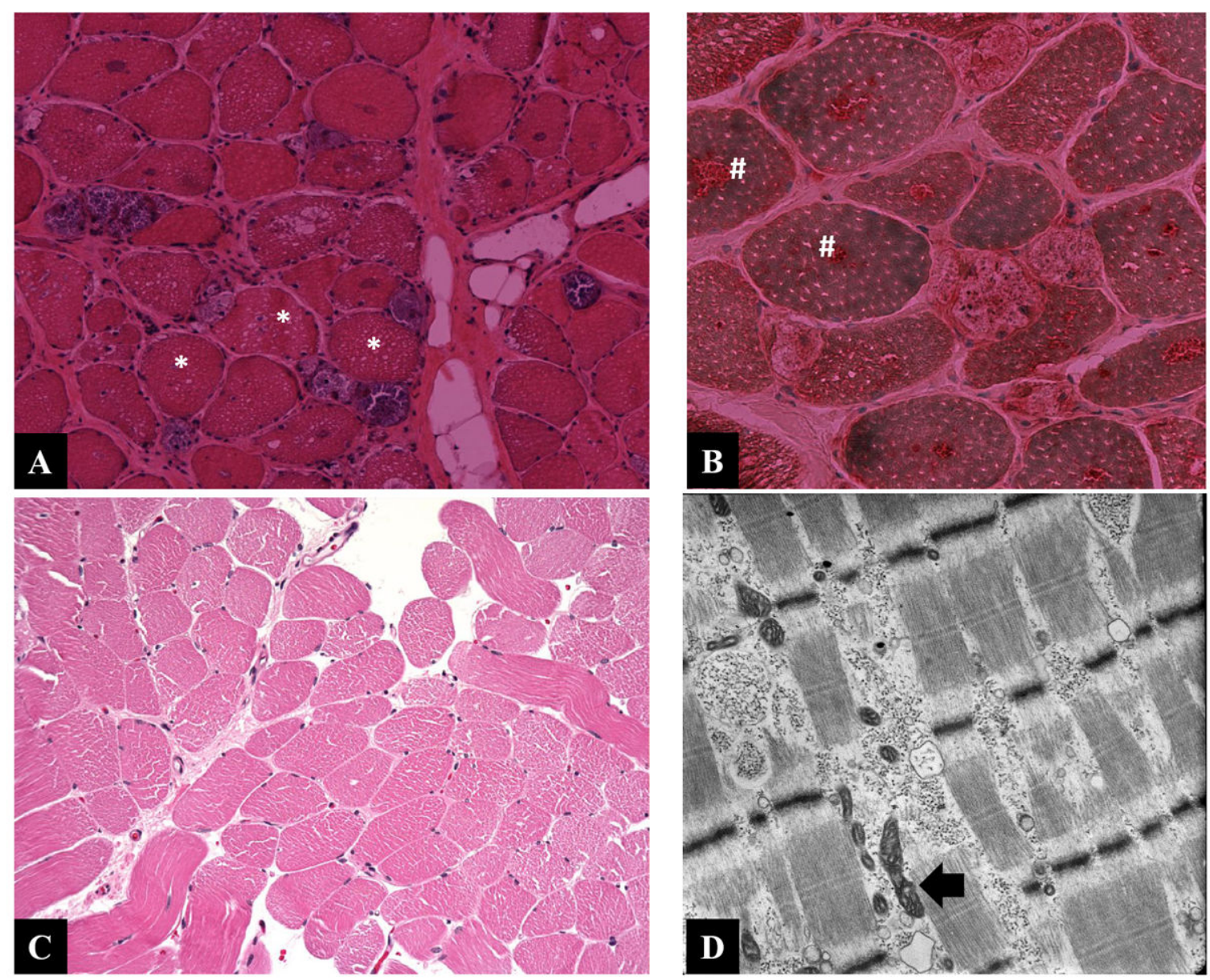

Figure 2.

Histological examination of muscle biopsies of patients 9 (A, B) and 4 (C, D). H\&E stained muscle biopsy (A) from patient 9 shows extensive vacuolar changes (asterisk) and positive acid phosphatase aggregates (\#) in panel B. The H\&E stained muscle biopsy (C) from patient 4 is essentially unremarkable while the muscle electron micrograph (D) showed membrane bound glycogen deposits and mildly distorted mitochondrial morphology. 

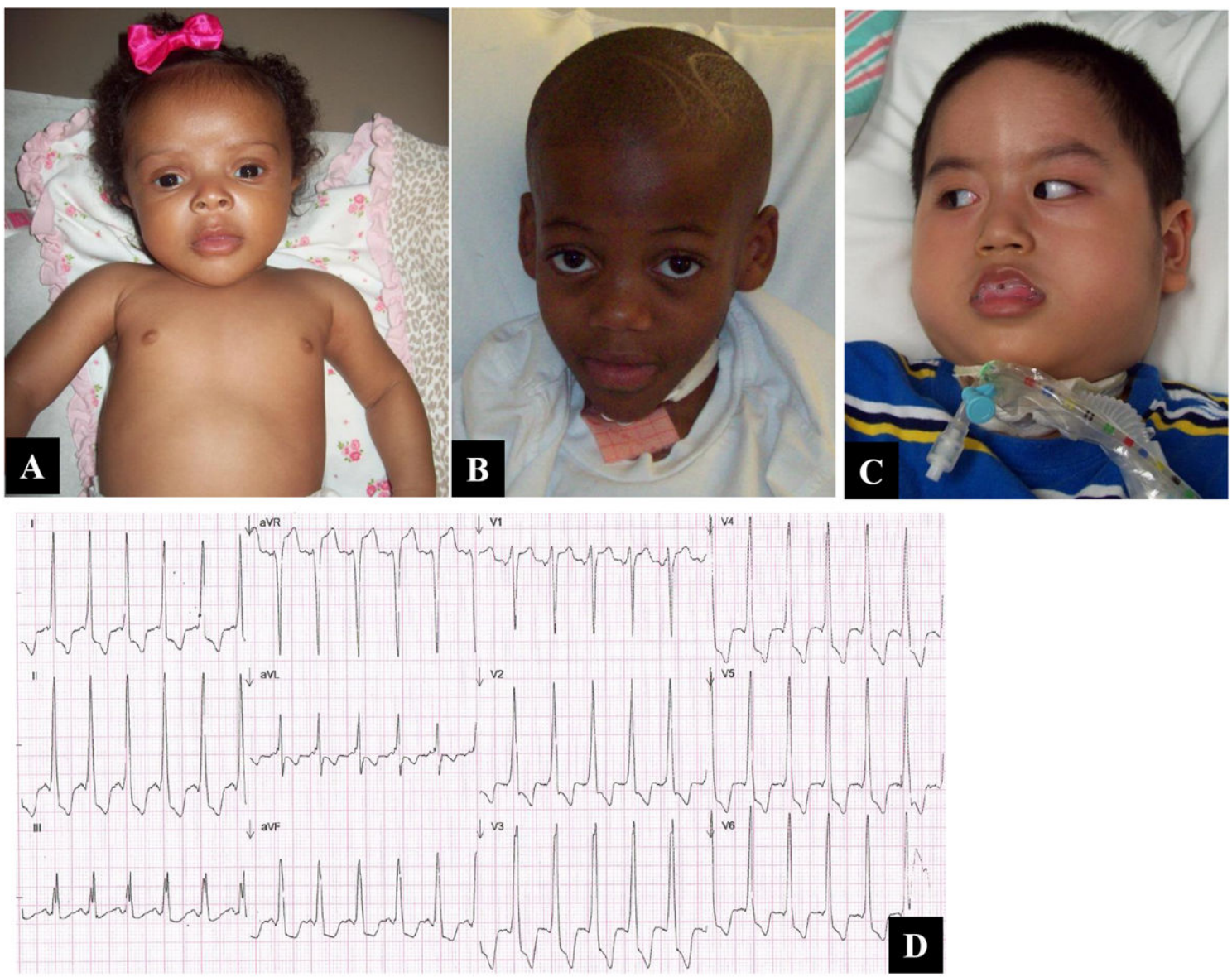

Figure 3.

Photographs of patients with infantile onset Pompe disease. The sib pair (A, B; patients 1 and 2 respectively) have non-classical IOPD while patient $3(\mathrm{C})$ has classical IOPD with macroglossia, tracheostomy and severe hypotonia. Abnormal EKG of patient 3 shows sinus tachycardia, short PR interval, ST segment and T wave abnormalities as well as left ventricular hypertrophy. 


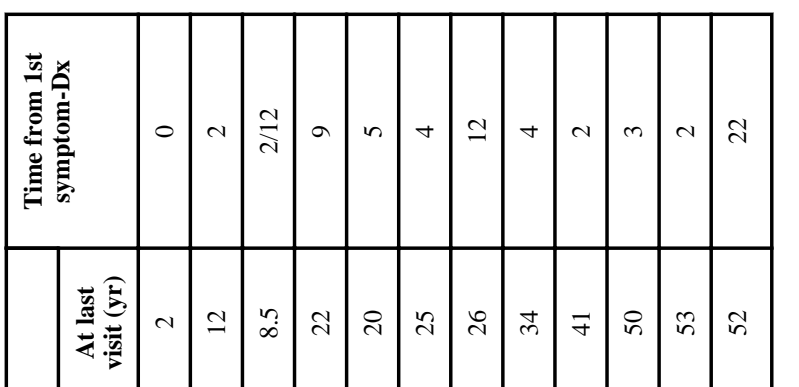

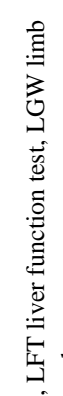
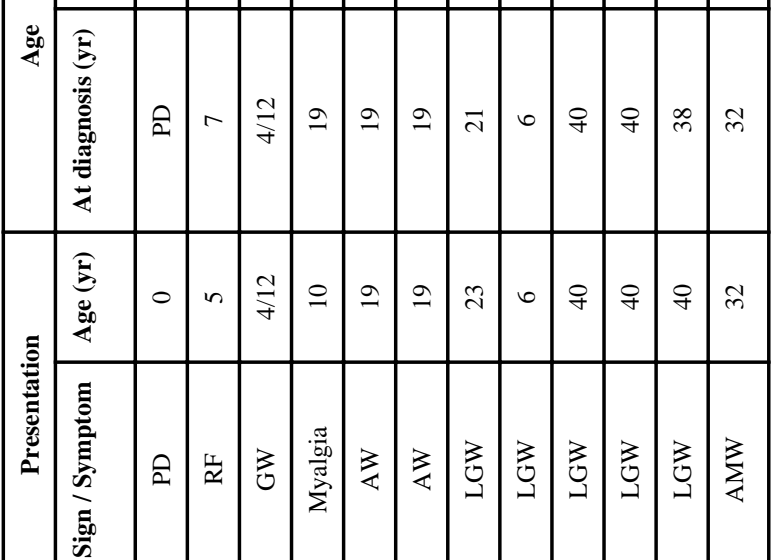

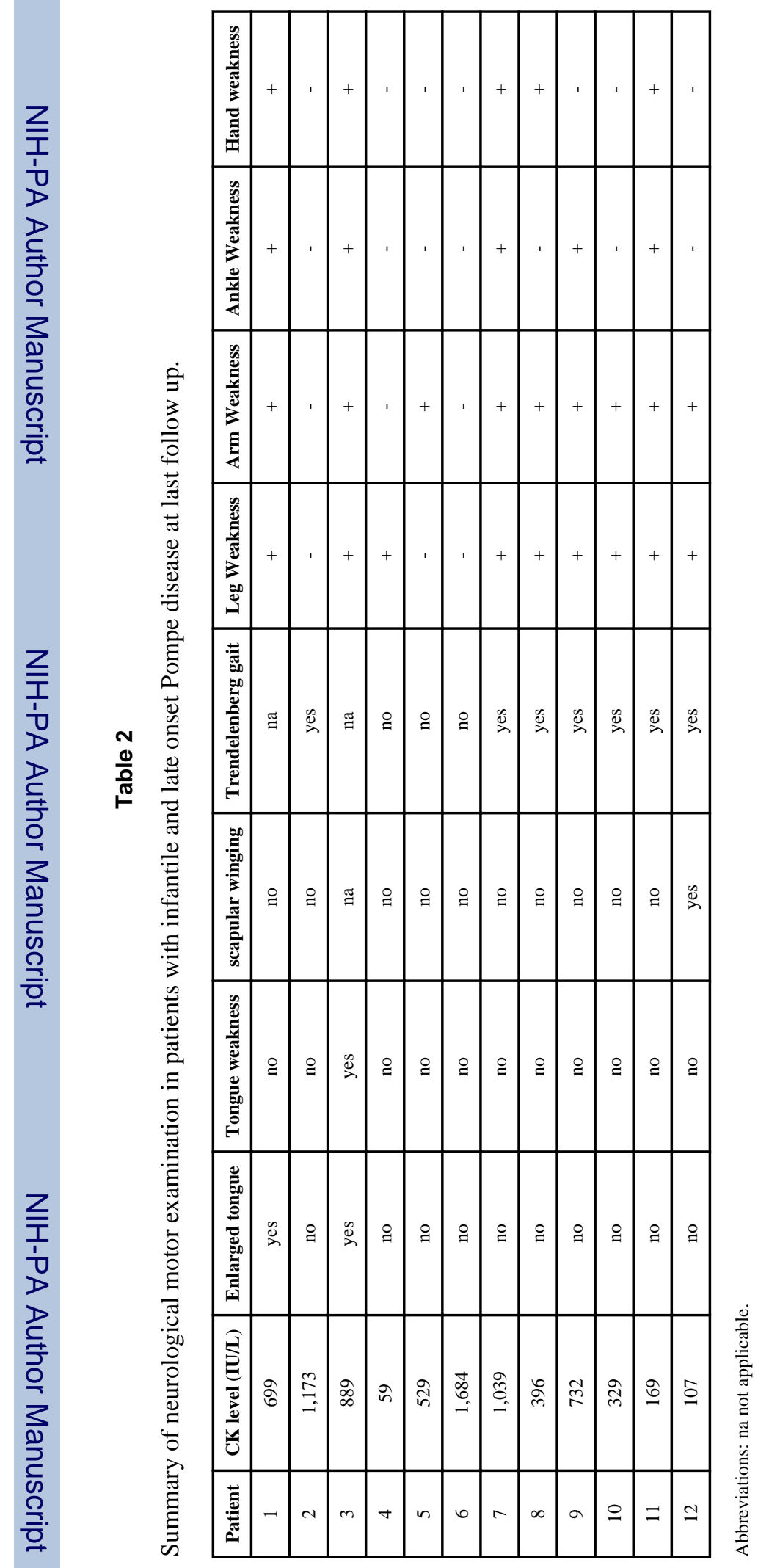
Table 3

\section{Respiratory status in patients with infantile and late onset Pompe disease}

In this group of patients, 4/12 (33\%) needed assistive ventilation including invasive ventilation in the 2 patients with infantile Pompe disease.

\begin{tabular}{|c|c|c|}
\hline Patient & FVC $(\mathbf{L})$ & Ventilatory support (onset in years) \\
\hline 1 & - & - \\
\hline 2 & 0.96 & Tracheostomy/5 \\
\hline 3 & - & Tracheostomy/0.5 \\
\hline 4 & 4.6 & - \\
\hline 5 & - & - \\
\hline 6 & 5.08 & - \\
\hline 7 & 3.8 & - \\
\hline 8 & 4.06 & BiPAP/39 \\
\hline 9 & 1.7 & - \\
\hline 10 & 3.15 & $\mathrm{BiPAP} / 48$ \\
\hline 11 & 2.00 & - \\
\hline 12 & 4.14 & \\
\hline
\end{tabular}

Abbreviations: BiPAP (Bi-Level Positive Air Pressure), FVC forced vital capacity, L liter. 


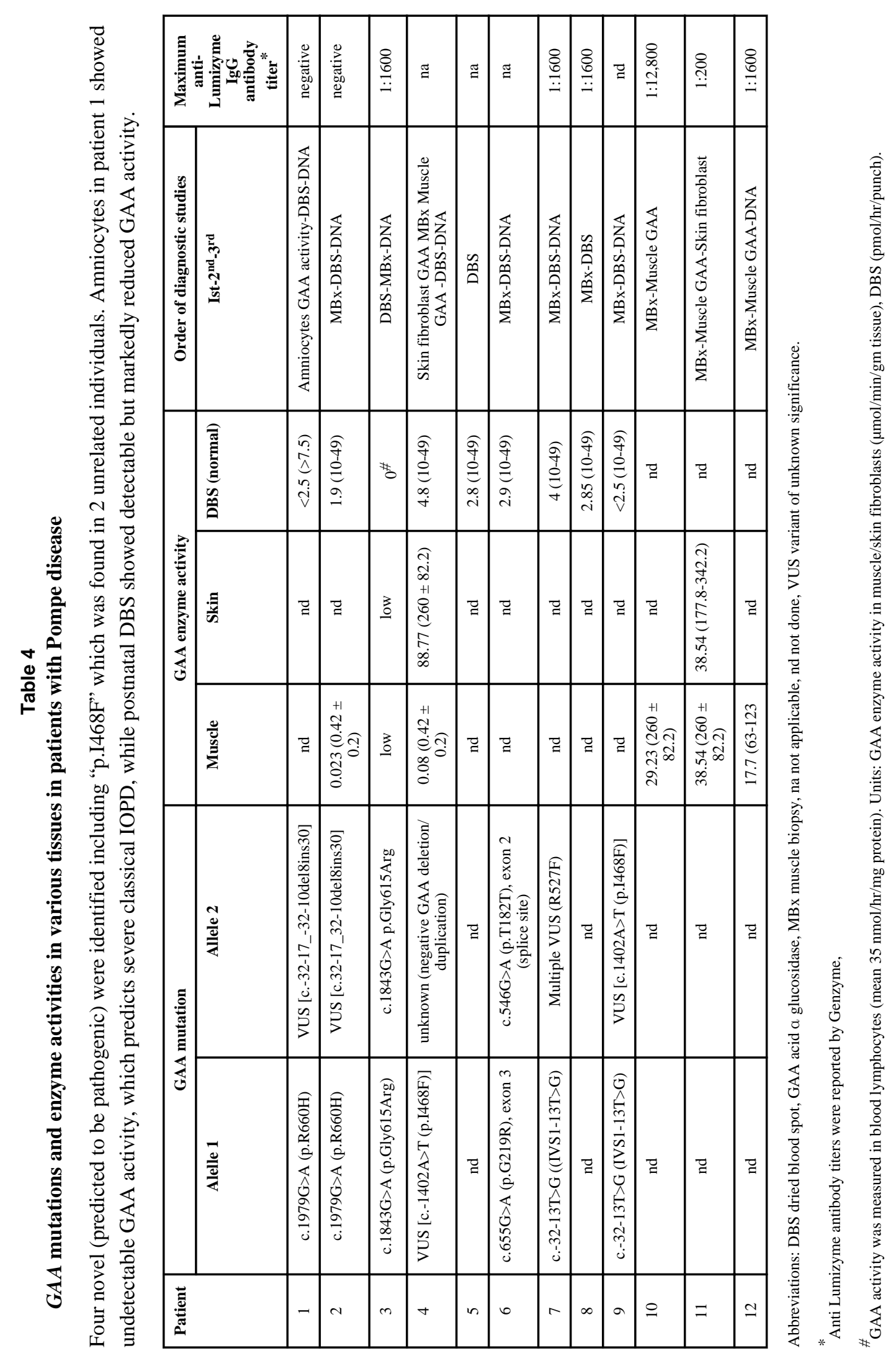

Neurol Clin. Author manuscript; available in PMC 2015 August 01. 


\section{Table 5}

Newborn screening studies for Pompe disease.

\begin{tabular}{|c|c|c|c|c|}
\hline Country & Newborns screened & Screening Method/Criteria & Outcome & Ref. \\
\hline \multirow[t]{2}{*}{ USA-Washington } & 111,544 & $\begin{array}{l}\text { MS/MS; cutoff of }<2.60 \mathrm{mmol} / \mathrm{h} / \mathrm{L} \\
(<15 \% \text { of mean })\end{array}$ & $\begin{array}{l}4 \text { PD cases }(1 / 27,800), 3 \\
\text { carriers with an additional } \\
\text { pseudodeficiency allele, } 6 \\
\text { were heterozygotes for a } \\
\text { pseudodeficiency allele only; } \\
\text { PPV } 0.24 ; \text { FPR } 1 / 8600\end{array}$ & 86 \\
\hline & 5055 & $\begin{array}{l}\text { MS/MS; cutoff: }<20 \% \text { daily mean } \\
\text { activity }\end{array}$ & 5 with low GAA activity & 87 \\
\hline USA-Missouri & 27,724 & digital microfluidics & $\begin{array}{l}3 \text { PD cases }(1 / 8,657): 1 \\
\text { classic, } 1 \text { non-classic IOPD \& } \\
1 \text { LOPD; } 3 \text { false positive } \\
\text { results (carrier status } \\
\text { unknown), } 1 \\
\text { pseudodeficiency, } 2 \text { carriers, } 2 \\
\text { pending cases }\end{array}$ & 88 \\
\hline USA-Illinois & 8,012 & digital microfluidics & 2 false positive & 89 \\
\hline \multirow[t]{2}{*}{ Taiwan } & $344,056(2005-2009)$ & $\begin{array}{l}\text { fluorescence assay, NAG/GAA }>60 \& \\
\text { GAA inhibition by acarbose }>80 \%, 2^{\text {nd }} \\
\text { tier: lymphocyte GAA activity }<5 \% \text { of } \\
\text { normal mean \& GAA activity in skin } \\
\text { fibroblasts, GAA sequencing }\end{array}$ & $\begin{array}{l}13 \text { LOPD }(1 / 26,466) \& 6 \\
\text { IOPD cases }\end{array}$ & 90 \\
\hline & $473,738(2005-2011)$ & $\begin{array}{l}\text { fluorescence assay, NAG/GAA ratio } \geq \\
100\end{array}$ & $\begin{array}{l}9 \text { IOPD \& } 19 \text { LOPD cases; } \\
\text { NAG/GAA cutoff ratio } \geq 60 \\
(P P V) \text { of } 63.4 \%\end{array}$ & 91 \\
\hline Japan & $\begin{array}{l}496 \text { healthy controls, } 29 \text { PD cases } \\
\& 5 \text { PD carriers ( } 530 \text { DBS) }\end{array}$ & $\begin{array}{l}\text { GAA activity }<8 \% \text { of normal mean \& } \% \\
\text { GAA inhibition }>60 \% \text { and NAG/GAA } \\
\text { ratio }>30\end{array}$ & $\begin{array}{l}5 \text { healthy pseudodeficiency } \\
\text { homozygots \& } 1 \text { obligate } \\
\text { carrier }\end{array}$ & 92 \\
\hline Italy & 3403 & $\begin{array}{l}\text { Fluorescent GAA activity; cutoff: }<35 \% \\
\text { of average control activities }\end{array}$ & $\begin{array}{l}3 \text { cases with low GAA activity } \\
\text { (final status not confirmed) }\end{array}$ & 93 \\
\hline Hungary & 40,024 & $\begin{array}{l}\text { MS/MS followed by molecular } \\
\text { confirmation }\end{array}$ & 9 PD cases & 94 \\
\hline \multirow[t]{2}{*}{ Germany } & 3251 & \multirow{2}{*}{$\begin{array}{l}\text { MS/MS \& fluorimetric assays; repeat } \\
\text { testing in }<0.5 \% \text { of DBS samples }\end{array}$} & No PD cases & 95 \\
\hline & 944 (symptomatic individuals) & & $\begin{array}{l}14 \text { PD cases and } 8 \text { GAA } \\
\text { carriers }\end{array}$ & \\
\hline Colombia & $\begin{array}{l}4700 \text { (DBS samples from } \\
\text { symptomatic, high risk } \\
\text { individuals; } 3 \text { months - } 73 \text { years } \\
\text { old)) }\end{array}$ & $\begin{array}{l}\text { Fluorometric microfluidic, molecular } \\
\text { GAA analysis (some) }\end{array}$ & 16 PD cases & 96 \\
\hline Austria & 34,736 (January - July, 2010) & ESI-MS/MS & $\begin{array}{l}4 \text { confirmed by } G A A \text { mutation } \\
\text { analysis }(1 / 8684) . \text { Most } G A A \\
\text { missense mutations were } \\
\text { LOPD; PPV } 80 \% ; 1 \text { false } \\
\text { positive case (FPR } 30 \text { per } \\
\text { million) }\end{array}$ & 97 \\
\hline
\end{tabular}

Abbreviations: acid glucosidase (GAA), false positive rate (FPR), infantile onset Pompe disease (IOPD), late onset Pompe disease (LOPD), MS/MS tandem mass spectrometry, neutral alpha-glucosidase (NAG), Pompe disease (PD), positive predictive value (PPV). 